\title{
DEMOKRASI DI PAKISTAN MENURUT BENAZIR BHUTTO
}

\author{
Irnawati \\ Universitas Brawijaya, Jl. Veteran, Malang65I45 | md_irnaa@gmail.com
}

\begin{abstract}
This article discusses about democracy in Pakistan by Benazir Bhutto. The realization of democracy in Pakistan, according to Benazir Bhutto, is to reach all the democratic elements of the Pakistani nations, the business communities, to release all of the political prisoners, to make the print and electronic media free, to open and uncensored, to remove the ban on sororities and labor, to separate the judicial functions of the executive, and to provide the basis for a fair electoral process. The other leaderships of women in Pakistan's democracy by Benazir Bhutto, are appointing some women to sit in the cabinet and set up the Ministry of Women Development, creating the program of study in the universities for women, founding the Women Development Bank to provide credit only for the women entrepreneurs, creating institutions to train women in family planning, nutrition counseling, child care, and birth control. Democracy in Pakistan is a liberal democracy which is characterized by a moderate Islam, by recruiting people who are competent to sit in the government, eliminating and restricting military power, reactivating the role of civil society in accordance with the government's program.

Keywords: Democracy, Pakistan, Benazir Bhutto.
\end{abstract}

Abstrak: Artikel ini membahas tentang demokrasi di Pakistan menurut Benazir Bhutto. Wujud demokrasi di Pakistan menurut Benazir Bhutto adalah menjangkau semua elemen demokratis bangsa Pakistan yang dipimpinnya, kepada komunitas bisnis, membebaskan semua tawanan politik, membuat media cetak dan elektronik kembali bebas, terbuka, dan tanpa sensor, dan menghapus larangan perkumpulan mahasiswa dan buruh, serta memisahkan fungsi peradilan dari eksekutif, memberikan dasar untuk proses pemilihan umum yang adil. Adapun kepemimpinan perempuan dalam demokrasi di Pakistan menurut Benazir Bhutto antara lain; menunjuk beberapa wanita untuk duduk dalam kabinet dan mendirikan Kementerian Perkembangan Wanita, 
menciptakan Program studi wanita di universitas, mendirikan Bank Pembangunan Wanita untuk memberi kredit hanya pada wanita pengusaha, menciptakan institusi untuk membantu melatih wanita dalam keluarga berencana, konseling gizi, perawatan anak, dan pengendalian kelahiran. Demokrasi di Pakistan merupakan demokrasi liberal yang bercirikan Islam moderat, dengan merekrut orang-orang yang kompeten untuk duduk dalam kursi pemerintahan, mengeliminasi dan membatasi kekuasaan militer, mengaktifkan kembali peran masyarakat sipil yang sesuai dengan program pemerintahan.

Kata Kunci: Demokrasi, Pakistan, Benazir Bhutto

\section{Pendahuluan}

Setiap manusia telah dianugerahi hak asasi manusia oleh Allah SWT. Akan tetapi manusia terbatas dalam menyampaikan pendapat, karena kurangnya perhatian dari pemerintah. Oleh karena itu kebebasan menyampaikan pendapat harus dikembangkan dalam kehidupan bermasyarakat, berbangsa dan bernegara. Agar aspirasi masyarakat dapat tersalurkan, sehingga tercipta kehidupan yang adil dan sejahtera. Sejauh ini, masyarakat kurang memiliki pengetahuan mengenai tata cara menyampaikan pendapat, sehingga masyarakat cenderung pasif dan tidak berkembang.

Kemerdekaan berfikir dan kebebasan berpendapat merupakan bagian dari kebebasan berekspresi (freedom of expression), yaitu kebebasan manusia untuk mengekspresikan diri dalam kehidupan masyarakat sebagai pengejewantahan kemampuan nalar dan kemampuan rasa manusia. Aspek lain yang terkait dalam lingkup kebebasan berekspresi adalah kebebasan berkesenian dalam segala bentuk dan manifestasinya. Kebebasan berpendapat pada dasarnya adalah kebebasan manusia untuk mengungkapkan pikiran dan pendapatnya mengenai masalahmasalah kemanusiaan dan kemasyarakatan. ${ }^{1}$

http://rifalittleduck.wordpress.com/20 13/0 I/06/hak-warga-negara-dalam-kebebasan-berfikirmenyampaikan pendapat/ diakses 20 Mei 2013

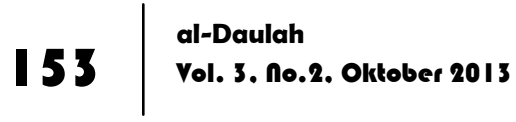


Kebebasan berpendapat adalah hak bagi warga negara biasa yang wajib dijamin dengan undang-undang dalam sebuah sistem politik demokratis. Kebebasan ini diperlukan karena kebutuhan untuk menyatakan pendapat senantiasa muncul dari setiap warga negara dalam era pemerintahan terbuka saat ini. Jika ada persoalan yang sangat merugikan hak-hak warga negara dimana warga negara berharap agar kepentingannya dipenuhi oleh negara, maka warga negara berhak untuk menyampaikan keluhan tersebut secara langsung maupun tidak langsung kepada pemerintah. Warga negara dapat menyampaikan kepada pejabat, seperti lurah, camat, bupati, anggota DPRD/ DPR atau presiden, baik melalui perbincangan langsung, surat, media massa atau penulisan buku. Misalnya, jika seorang pedagang merasa dirugikan oleh pemerintah daerah karena tempat usahanya dirusak karena proyek pemerintah daerah, maka ia berhak menyampaikan keluhan-keluhan tersebut, baik secara langsung maupun tidak langsung kepada pemerintah daerah mulai dari yang paling rendah (lurah) maupun yang paling tinggi (presiden) atau kepada wakil rakyat yang ada di DPRD/ DPR.

Hak untuk menyampaikan pendapat ini wajib dijamin oleh pemerintah sesuai dengan undang-undang yang berlaku sebagai bentuk kewajiban negara untuk melindungi warga negaranya yang merasa dirugikan oleh tindakan pemerintah atau unsur swasta. Semakin cepat dan efektif cara pemerintah memberikan tanggapan, semakin tinggi pula kualitas demokrasi pemerintahan tersebut.

Kemerdekaan berfikir dan menyampaikan pendapat di muka umum adalah hak asasi manusia yang dijamin oleh pasal 28 UUD 1945 yang berbunyi: "Kemerdekaan berserikat dan berkumpul, mengeluarkan pikiran dengan lisan dan tulisan dan sebagainya ditetapkan ditetapkan dengan undang-undang". Pasal 19 deklarasi Universal Hak-Hak Asasi Manusia yang berbunyi: "Setiap orang berhak atas kebebasan mempunyai pendapat dengan tidak mendapat gangguan untuk mencari, menerima dan 
menyampaikan keterangan dan pendapat dengan cara apapun juga dan dengan tidak memandang batas-batas serta merupakan perwujudan demokrasi dalam tatanan kehidupan bermasyarakat, berbangsa dan bernegara". Agar dalam membangun demokrasi yang berkeadilan sosial dan menjamin hak asasi manusia diperlukan adanya suasana yang aman, tertib dan damai serta dilaksanakan secara bertanggung jawab sesuai dengan ketentuan peraturan perundang-undangan yang berlaku.

Dalam rezim otoriter, kebebasan menyampaikan pendapat pada umumnya dibatasi. Hanya pendapat-pendapat yang mendukung atau memuja rezim berkuasa saja yang diberi kesempatan untuk berkembang. Sebaliknya, pendapat yang miring atau bahkan bertolak belakang dengan garis kebijakan rezim dianggap sebagai ancaman bagi rezim yang berkuasa. Bila pendapat ini disalurkan melalui tulisan, buku, produk seni, dll., maka pemerintah represif akan melarang peredaran atau perwujudan produk tersebut. Bila pendapat disampaikan oleh tokoh politik atau tokoh masyarakat, sang tokoh tersebut akan dilarang untuk menyatakan pendapatnya lagi. Dalam praktik, tokoh tersebut akan diamankan (dijebloskan ke dalam penjara). Tidak jarang tokoh-tokoh tersebut akan disiksa agar mengaku bersalah dan tidak mengulang kembali kesalahan tersebut.

Di masa orde baru, tindakan pemasungan kemerdekaan berfikir dan kebebasan berpendapat berlangsung secara intensif dan sistematis. Sistem intelijen negara dioperasionalkan secara maksimal untuk memantau setiap pendapat yang muncul dan gerak-gerik tokoh masyarakat. Para intelijen sangat represif dan terlalu sering melanggar hak-hak asasi manusia untuk menindas kebebasan berpendapat tersebut.

Penindasan ini mengakibatkan matinya nilai-nilai demokrasi di republik Indonesia. Dengan kematian ini rezim orde baru dapat leluasa menentukan kebijakan negara sesuka hatinya. Namun dalam jangka panjang, akibatnya sangat parah. Kasus represi terhadap perbedaan pendapat dengan penguasa cukup potensial

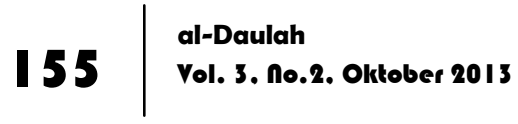


menyebabkan disintegrasi bangsa. Demokrasi mengajarkan kebebasan menyatakan pendapat, namun sudah tentu berada dalam koridor yang memerlukan kesepakatan kolektif. Jelaslah bahwa penindasan kebebasan berfikir dan berpendapat merupakan penghalang besar bagi demokrasi, sehingga harus dihindarkan sejauh mungkin dari tata kehidupan politik di Indonesia agar negara kita tidak terjerumus kembali ke dalam krisis politik dan ekonomi seperti yang dialami Indonesia saat ini. Kebebasan berfikir dan menyatakan pendapat diperlukan karena dalam era keterbukaan saat ini perubahan-perubahan cepat yang terjadi di masyarakat memerlukan tanggapan dan sikap dari warga negara sesuai haknya.

\section{Kemerdekaan Berfikir Bagian dari Hak Politik}

Ciri paling mendasar dari setiap sistem demokrasi adalah ide bahwa para warga negara seharusnya terlibat dalam hal tertentu dibanding pembuatan keputusan-keputusan politik, baik langsung maupun melalui para wakil pilihan mereka. Keterlibatan warga negara memiliki sejumlah unsur penting lainnya. Unsur-unsur ini mencakup partisipasi aktif dalam suatu partai politik atau kelompok penekan, atau menghadiri dan berpartisipasi dalam dengar pendapat publik atau rapat-rapat politik yang lain. Bahkan tindakan sederhana untuk membicarakan politik merupakan suatu tindakan keterlibatan dalam proses politik, seperti menyampaikan ide atau pemikiran pada seorang pejabat resmi. Namun ciri utama rumusan demokrasi adalah adanya keterlibatan atau partisipasi warga negara, baik secara langsung maupun tak langsung (melalui pemilihan) di dalam proses-proses pemerintahan.

Sistem demokrasi dipercaya sebagai suatu sistem yang mencerminkan mekanisme politik yang dianggap mampu menjamin adanya pemerintah yang tanggap terhadap preferensi dan keinginan warga negaranya. ${ }^{2}$

2 Muladi, Hak Asasi Manusia, (Bandung: PT.Refika Aditama, 2005), 76.

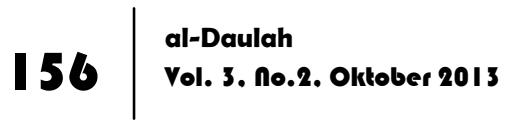


Robert A.Dahlan, mengemukakan bahwa dalam sistem demokrasi paling tidak ditunjukkan oleh lima prinsip, yakni:

a. Adanya prinsip hak yang tidak diperbedakan antara rakyat yang satu dengan yang lainnya;

b. Adanya partisipasi efektif yang menunjukkan adanya proses dan kesempatan yang sama bagi rakyat untuk mengekspresikan preferensinya dalam keputusan-keputusan yang diambil;

c. Adanya pengertian yang menunjukkan bahwa rakyat mengerti dan paham terhadap keputusan-keputusan yang diambil negara, tidak terkecuali birokrasi;

d. Adanya kontrol akhir yang diagendakan oleh rakyat, yang menunjukkan bahwa rakyat mempunyai kesempatan istimewa untuk membuat keputusan dan dilakukan melalui proses politik yang dapat diterima dan memuaskan berbagai pihak;

e. Adanya inclusiveness yakni suatu pertanda yang menunjukkan bahwa yang berdaulat adalah seluruh rakyat.

Prinsip-prinsip tersebut di atas dipercaya akan mampu menjamin keadilan demokrasi yaitu bahwa semua warga negara akan diperlakukan sama dalam sebuah penyelenggaraan negara. Persamaan tersebut mengimplikasikan bahwa semua lapisan masyarakat mempunyai hak untuk akses dalam proses penyelenggaraan pemerintahan tanpa ada perbedaan.

Ketentuan serupa juga terdapat dalam Undang-Undang Nomor 39 Tahun 1999 pada bagian kedelapan Pasal 43 tentang Hak Turut Serta Dalam Pemerintahan. Ketentuan-ketentuan itu merupakan landasan penting bagi warga masyarakat yang memberikan kesempatan bagi warga untuk melaksanakan hak asasinya dalam partisipasi publik pada proses penyelenggaraan pemerintah yang demokratis di Indonesia. ${ }^{3}$

Di negara-negara yang sudah maju, seorang anggota partai/golongan tertentu, sering berbeda pendapat, malah

${ }^{3}$ Muladi, Hak Asasi Manusia, 77.

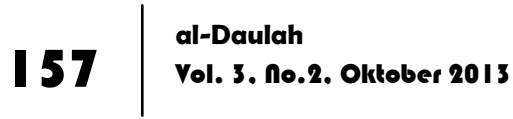


menentang kebijaksanaan/keputusan politik partainya secara terbuka. Sebaliknya dalam negara berkembang belum nampak jelas, hal ini adanya lembaga recall sering mengganggu hak individu tersebut. Sementara ada yang berpendapat, kebebasan berbicara harus lewat orpolnya/golongannya/fraksinya yang menunjukkan adanya keutuhan dan keyakinan akan kebenaran keputusan yang sama-sama disepakati. Sebaliknya ada pula pendapat yang mengatakan bahwa, ketentuan tersebut mengebiri kebebasan individualnya atau menunjukkan adanya mekanisme yang tidak berjalan dengan baik, di samping tidak menumbuhkan sikap kritis yang sangat diperlukan dalam kebebasan berpolitik.

Bagaimanapun sistem pemerintah/sistem politik suatu negara dapat dikatakan modern dan demokratik, bilamana keputusankeputusan yang menyangkut rakyat diserahkan sepenuhnya pada rakyat sendiri, bukan kemauan negara. Penyerahan yang dilaksanakan lewat kesepakatan terbuka tersebut, akan membangkitkan kepercayaan rakyat sendiri. ${ }^{4}$

Proses partisipasi rakyat dalam penyelenggaraan pemerintahan akan sangat ditentukan oleh kualitas hubungan antara pemerintah dan warga. Pemerintah sebagai lembaga yang memiliki kekuasaan yang lebih superior harus dengan tulus membuka ruang dan kesempatan bagi warga untuk ikut dalam proses penentuan kebijakan. Di lain pihak warga harus juga proaktif untuk mengakses informasi dan mengajukan pendapatpendapatnya atas sebuah kebijakan yang akan diambil oleh pemerintah.

M. Budairi Idjehar mengemukakan bahwa kesempatan bagi rakyat hanya mungkin tersedia kalau lembaga-lembaga dalam masyarakat menjamin adanya 7 kondisi,yaitu:

a. Kebebasan untuk membentuk dan bergabung dalam organisasi;

b. Kebebasan mengeluarkan pikiran/pendapat;

${ }^{4}$ Masyhur Effendi, HAM dalam Hukum Nasional dan Internasional, (Jakarta: Ghalia Indonesia, 1994), 49. 
c. Hak untuk memilih dalam pemilihan umum;

d. Hak untuk menduduki jabatan politik;

e. Hak para pemimpin untuk bersaing memperoleh dukungan suara;

f. Tersedianya sumber-sumber informasi alternatif;

g. Terselenggaranya pemilihan umum yang bebas dan jujur;

Ketujuh kondisi tersebut akan mengimplikasikan pada terbukanya ruang pertisipasi publik dalam penyelenggaraan pemerintahan secara luas. Dengan terbukanya ruang partisipasi tersebut maka pengambilan keputusan yang menyangkut masyarakat tidak dapat dimonopoli oleh pejabat pengambil keputusan maupun anggota lembaga perwakilan, melainkan harus dibuka secara luas dalam iklim keterbukaan. Warga masyarakat adalah pihak yang mungkin akan dirugikan oleh sebuah kebijakan yang diambil oleh penguasa dan berkeberatan atas kebijakan tersebut. Terhadap keberatan warga masyarakat, pemerintah perlu mendengarkan keluhan dan harapan warga atas kebijakan yang diambil oleh penguasa. Selain itu, pelibatan masyarakat secara langsung akan memberikan makna pada kepastian hukum atas keputusan penguasa agar keputusan tersebut tidak digugat oleh warga masyarakat di kemudian hari. Melalui proses partisipasi yang tulus maka warga akan menerima kebijakan penguasa secara tulus pula.

Nurcholish Madjid mengemukakan dalam tulisannya yang berjudul "Demokrasi dan Kebebasan" dalam tabloid Tekad (1999) bahwa kekuatan demokrasi ialah sebuah sistem yang mampu melalui dinamika internnya sendiri untuk mengadakan kritik kedalam dan perbaikan-perbaikan, berdasarkan prinsip keterbukaan serta kesempatan bereksperimen. Keterbukaan pemerintahan memungkinkan peran serta masyarakat dalam pengmbilan keputusan. Untuk itu dibutuhkan sarana peran serta, misalnya sarana keberatan, dengar pendapat, komisi pertimbangan dll. Di samping itu asas keterbukaan mewajibkan pemerintah untuk mengumumkan setiap keputusannya. Pendapat 
tersebut memberikan gambaran bahwa dalam keterbukaan pemerintahan, warga mempunyai hak dan kesempatan untuk tahu atas rencana-rencana atau keputusan-keputusan yang akan diambil, hak dan kesempatan untuk berfikir dan memutuskan suatu kebijaksanaan pemerintahan melalui sarana peran serta. Untuk kepentingan tersebut maka diperlukan adanya informasi yang terbuka prosedur yang memungkinkan peran serta bagi warga dan pengumuman. ${ }^{5}$

Asas keterbukaan mewajibkan pemerintah untuk secara aktif memberikan informasi kepada masyarakat tentang suatu permohonan atau suatu rencana tindak pemerintahan dan mewajibkan untuk memberikan penjelasan kepada masyarakat atas hal yang diminta. Terhadap kewajiban pemerintah untuk memberikan informasi, peraturan perundang-undangan di Indonesia belum ada ketentuan yang memadai. Dalam tatanan peraturan pemerintah daerah belum ada pengaturan yang menjamin akses rakyat atas informasi kebijakan-kebijakan yang akan dilakukan. Informasi merupakan barang yang sangat mahal dan eksklusif. Para pejabat seringkali menutup akses masyarakat atas informasi dengan alasan "rahasia negara". ${ }^{6}$

Ketentuan mengenai partisipasi atau peran serta masyarakat diatur dalam UU Nomor 28 Tahun 1999 tentang Penyelenggaraan Negara yang Bersih dan Bebas dari KKN. Pasal 8 ayat (1) UU tersebut menentukan bahwa peran serta masyarakat dalam penyelenggaraan negara merupakan hak dan tanggung jawab masyarakat untuk ikut mewujudkan penyelenggaraan negara yang bersih. Selanjutnya dalam ayat (2) menentukan bahwa hubungan antara penyelenggara negara dan masyarakat dilaksanakan dengan berpegang teguh pada asas-asas umum penyelenggaraan negara. Asas-asas umum penyelenggaraan negara diatur dalam pasal 3 meliputi: asas kepastian huum, asas

\footnotetext{
${ }^{5}$ Masyhur Effendi, HAM dalam Hukum Nasional dan Internasional, 80.

${ }^{6}$ Muladi, Hak Asasi Manusia, 81 .
} 
tertib penyelenggaraan negara, asas kepentingan umum, asas keterbukaan, asas proposionalitas, dan asas akuntabilitas. ${ }^{7}$

Sikap proaktif masyarakat mempunyai risiko tersendiri, terutama bila menunjukkan sikap keberatan atau sikap kritis terhadap sebuah kebijakan, sering dihadapkan pada ancamanancaman kekerasan fisik sampai dengan kesulitan dalam memperoleh pelayanan publik yang dibutuhkan. Sikap arogan dan anti kritik para birokrat masih demikian kental dan untuk itu masyarakat tidak memproleh jaminan perlindungan. Jaminan perlindungan dapat dilakukan dengan melakukan perlawanan melalui proses peradilan yang sangat membutuhkan biaya dan waktu yang panjang.

Pada dasarnya UU menjamin hak warga masyarakat untuk menyampaikan saran dan pendapat secara bertanggung jawab terhadap kebijakan penyelenggara negara, akan tetapi hak tersebut akan sulit terwujud karena tidak ada kewajiban bagi pemerintah bahwa saran dan pendapat tersebut akan mempengaruhi keputusan yang diambilnya. Pengalaman dalam melakukan advokasi APBD menunjukkan bahwa pemikiran dari berbagai kalangan, yaitu antara lain perguruan tinggi dan elemen-elemen masyarakat yang tergabung dalam Jaringan Pemantau Transparansi dan Otonomi Daerah (JMPTOD) tidak didengar sama sekali. Dalam hal ini telah terjadi penghianatan atas aspirasi yang telah disampaikan kepada dewan, dan tidak ada jaminan bahwa apa yang telah disampaikan oleh warga masyarakat akan mempengaruhi keputusan yang akan diambil. Demikian pula dalam proses pemilihan gubernur yang beraroma politik uang, proses pemilihan yang seharusnya dilandasi dengan semangat demokratis, ternyata dilakukan secara eksklusif dan tertutup. Ruang publik bagi masyarakat untuk melakukan partisipasi atau peran serta dalam proses pemilihan kepala daerah hanyalah retorika semata. Superioritas pemerintah dan sikap mental para

${ }^{7}$ lbid, 82. 
birokrat masih demikian dominan sehingga menghambat proses partisipasi politik. ${ }^{8}$

\section{Kemerdekaan Berfikir Bagian dari Hak Asasi Manusia}

Pasal 26 sampai dengan 31 UUD 1945 berbicara tentang hakhak warga negara. Dalam penjelasan bab X UUD 1945 rumusan hak-hak manusia dikaitkan dengan hasrat bangsa Indonesia untuk membangun negara yang bersifat demokratis dan yang hendak menyelenggarakan keadilan sosial dan kemanusian. Rumusan lebih lanjut dalam perundang-undangan jelas harus mengikuti petunjuk-petunjuk ini, dan dimungkinkan adanya pembatasanpembatasan terhadap sifat mutlak yang lazim dikaitkan pada masalah hak kemanusiaan ini. ${ }^{9}$

Kemerdekaan berserikat dan berkumpul, mengeluarkan pikiran dengan lisan dan tulisan sebagaimana disebutkan dalam pasal 28 UUD 1945. Indonesia adalah sebuah negara yang demokratis. Maka ada kebebasan untuk berorganisasi, membentuk perkumpulan, dan mengadakan pertemuan-pertemuan. Begitu pula kebebasan untuk menyatakan pendapat atau keinginan. Tetapi demokrasi Indonesia bukan demokrasi liberal yang berdasarkan individualisme. Demokrasi Indonesia berdasarkan ideologi pancasila. Oleh karena itu kebebasan berfikir, mengekspresikan gagasan dan keinginan harus disertai dengan kesadaran tanggung jawab kepada Tuhan, dengan memperhatikan harkat dan martabat sesama manusia seperti dirinya sendiri. Kebebasan-kebebasan ini harus dipergunakan untuk memperkokoh persatuan dan kesatuan bangsa, dalam suasana "musyawarah untuk mufakat" dengan tukar pikiran sehingga dengan demikian dapat bersama-sama menemukan kebenaran dan kebahagiaan bersama. ${ }^{10}$

${ }^{8}$ Muladi, Hak Asasi Manusia, 84.

${ }^{9}$ Padmo Wahyono, Indonesia Berdasarkan Atas Hukum, (Jakarta: Ghalia Indonesia, 1983), I0-I I .

${ }^{10}$ A. Gunawan Setiardja, HAM Berdasarkan Ideologi Pancasila, (Yogyakarta: Kanisius, 1993), 120. 
HAM adalah landasan dari kebebasan, keadilan, dan kedamaian. Sehingga hak asasi manusia mencakup semua yang dibutuhkan manusia untuk tetap menjadi manusia, dari segi kehidupan sipil, politik, ekonomi, sosial dan budaya. Dari segi politik, HAM dapat juga digunakan sebagai alat politik oleh salah satu negara terhadap negara yang lain, tetapi masyarakat sipil dapat juga mempergunakan HAM sebagai agenda untuk mengangkat ketidakadilan kemerdekaan berfikir dan sosial yang dialami masyarakat kecil. Karena pada dasarnya, HAM menentang arogansi kekuasaan. ${ }^{11}$

Dalam negara yang berdasarkan pancasila, pemahaman atas atas hak-hak asasi manusia dipandang penting, yaitu dengan menempatkan manusia dengan kodrat, harkat dan martabatnya. Kodrat manusia adalah keseluruhan sifat-sifat asli, kemampuankemampuan atau bakat-bakat alami, kekuasaan, bekal, disposisi yang melekat pada keberadaan manusia baik sebagai makhluk pribadi maupun makhluk sosial yang merupakan ciptaan Tuhan Yang Maha Esa. Harkat manusia adalah nilai manusia sebagai makhuk Tuhan, yang memiliki kemampuan-kemampuan cipta, rasa dan karsa, kebebasan, hak-hak serta kewajiban-kewajiban asasi. Martabat manusia adalah kedudukan luhur manusia sebagai makhuk Tuhan lainnya di dunia, karena manusia adalah makhuk yang berakal budi dan memiliki harkat berupa kemampuankemampuan tadi, dan dengan harkatnya yang tinggi memberi manusia martabat yang luhur. Derajat manusia adalah kodrat tingkat kedudukan atau martabat manusia sebagai ciptaan Tuhan yang memiliki bakat, kodrat, kebebasan, hak-hak maupun kewajiban-kewajiban asasi. ${ }^{12}$

Sehubungan dengan masalah kemerdekaan berpikir atau kebebasan mengeluarkan pendapat harus senantiasa diimbangi

\footnotetext{
" Muh.Budairi Idjehar, HAM versus Kapitalisme, (Yogyakarta: INSIST Press,2003), 91.

12 Suprapto, Cita Negara Pancasila, Demokrasi dan Hak Asasi Manusia, (Jakarta: FH UI,Seminar Sehari, 26 Januari 1995), 4.
} 
dengan eksistensi hak untuk berbeda pendapat. ${ }^{13}$ Hal ini sejalan dengan semakin transparansinya era keterbukaan, kian deras pula tuntutan untuk pemenuhan hak asasi baik yang bersifat individual maupun hak yang bersifat sosial. Di antara hak sosial yang bersifat asasi itu adalah hak untuk berbeda pendapat.

Berkenaan dengan ketentuan pasal 28 UUD 1945 secara tersurat memang tidak mencantumkan mengenai adanya hak untuk berbeda pendapat tersebut. Namun secara tersirat, hal itu termasuk di dalamnya. Sebab pada saat dinyatakan adanya hak untuk menyatakan pendapat maka secara alamiah pengedapanan hak tersebut tentu akan secara transparan berhadapan/berbenturan dengan hak yang sama yang dimiliki orang lain. Oleh karena itu merupakan kewajiban untuk menghormati pendapat tersebut dengan dasar keinginan untuk mencari titik temu di antara perbedaan pendapat yang muncul. ${ }^{14}$

Ada hal yang bersifat alami jika antara satu orang dengan yang lainnya tidak sama mengenai sesuatu yang akan dikemukakannya. Itulah sebabnya, pada saat muncul kebebasan hak untuk menyatakan pendapat, pada saat yang sama diikuti pula dengan hak untuk berbeda pendapat. Relevansinya dari adanya hak untuk berbeda pendapat ini adalah berkenaan dengan mekanisme penyelesaian kekusutan akibat ketidaksamaan pendapat mengenai sesuatu. Hak untuk berbeda pendapat termasuk hak yang amat penting. Oleh karena itu dibutuhkan adanya legalitas dalam bentuk peraturan yang secara eksplisit juga merefleksikan hak ini. Pengakuan adanya hak untuk berbeda pendapat ini mengharuskan pihak pemegang kekuasaan khususnya untuk membuka diri dan siap menerima berbagai masukan konkretnya adalah kritik dari pihak lain. Hendaknya

13 Samsul Wahidin, Wacana Hukum Kritik dan Hak untuk Berbeda Pendapat, (Surabaya: artikel pada harian surya, senin 23 maret 1998)

${ }^{14}$ Samsul Wahidin, Wacana Hukum Kritik dan Hak untuk Berbeda Pendapat, (Surabaya: artikel pada Harian Surya, senin 23 maret 1998) 
kritik yang di sampingkan tidak diartikan sebagai upaya perorangan terhadap kewibawaan dan kemapanan. ${ }^{15}$

Praktik selama ini menunjukkan adanya kecenderungan sebaliknya bahwa adanya kritik sebagai refleksi dari hak untuk berbeda pendapat ditanggapi sebagai sesuatu yang bersifat destruksi. ${ }^{16}$ Siapa yang mengemukakan bisa dianggap melakukan satu serangan konsep yang berakibat minimal tidak menyenangkan atau pada akhirnya akan mendatangkan kesulitan.

Di dalam perkembangannnya memang ada kecenderungan untuk tidak bersikap represif terhadap berbagai kritik yang dilontarkan. Hal ini kiranya dapat dijadikan sebagai momentum yang dipertahankan dengan catatan bahwa hendaknya dilakukan dengan rasa tanggung jawab. Untuk itulah, pada era demokrasi dan demokratisasi yang menuntut lebih banyak keterbukaan, kritik, sumbang saran atau apa pun namanya amat diperlukan sebagai refleksi dari hak untuk berbeda pendapat ini. Bukan sebagai sesuatu yang dianggap memusuhi. Pers adalah wadah perbedaan pendapat sebagai refleksi dari kebebasan mengeluarkan pikiran dan pendapat secara tertulis. Pembatasan terhadap kebebasan tanpa landasan yuridis yang jelas dan sesuai dengan asas legalitas akan menjadi pemicu munculnya konflik yang justru akan membahayakan persatuan dan kesatuan bangsa. ${ }^{17}$

\section{Kemerdekaan Berfikir dalam Perspektif Islam}

Salah satu dari tiang-tiang junjungan kita Nabi Muhammad s.a.w. yang penting ialah: menghargai akal manusia dan melindunginya dari pada tindasan-tindasan yang mungkin dilakukan orang atas nikmat Tuhan yang tiada ternilai itu. Nabi Muhammad s.a.w. meletakkan akal pada tempat yang terhormat

\footnotetext{
${ }^{15}$ Samsul Wahidin, Hukum Pers, (Yogyakarta:Pustaka Pelajar, 2006), 72.

16 lbid.

17 Samsul Wahidin, Hukum Pers, 73.
} 
dan menjadikan akal itu sebagai salah satu alat untuk mengetahui Tuhan.

Al Qur'an berkata, antara lain: “Adakah kamu perhatikan sesuatu yang kamu tanam?, "Kamukah yang menumbuhkannya atau kamikah yang menumbuhkannya?, "Adakah kamu perhatikan iar yang kamu minum?, "Kamukah yang menurunkannya dari awan atau kamikah yang menurunkannya?, "Adakah kamu perhatikan api yang kamu nyalakan dengan kayu?, "Kamukah yang menjadikan kayunya atau kamikah yang menjadikannya?. (Q.S. Al-Waqi'ah: 63-64; 68-69; 71-72). Siapakah diantara orang-orang yang berakal yang tidak akan terpikat hati dan perhatiannya oleh caranya Islam membawa manusia kepada mengetahui Tuhannya seperti yang terlukis dalam ayat-ayat yang kita turunkan di atas itu.

Dalam ajaran Islam, individu tidak berada di atas masyarakat tetapi dalam pada itu, masyarakat tak pula boleh merugikan individu. Dalam Islam kepentingan keduanya, individu dan masyarakat sama-sama dipentingkan. Kepentingan individu tidak boleh diabaikan, tetapi kepentingan masyarakat tidak pula boleh dikalahkan oleh kepentingan individu. ${ }^{18}$ Maka kebebasan dalam ajaran Islam mempunyai batas-batasnya. Kebebasan mengeluarkan pendapat tidak boleh melanggar kepentingan umum. Kebebasan mengumpulkan harta juga tidak boleh merugikan masyarakat. Kebebasan mengolah alam juga tidak boleh membawa kerusakan alam. ${ }^{19}$

Salah satu dari jasa Islam atas manusia dan kemanusiaan ialah mobilisasi akal, membuka dan menggerakkan akal manusia yang selama ini tidak mendapat tempat yang semestinya dalam kehidupan mana saja. Sudah pasti akan dirasa oleh setiap orang betapa besarnya dorongan Islam untuk memakai akal dan mempergunakan fikiran, sebagai satu nikmat Tuhan yang tidak ternilai harganya.

\footnotetext{
${ }^{18}$ Harun Nasution, HAM Dalam Islam, (Jakarta: Pustaka Firdaus, 1995), 12.

${ }^{19}$ Harun Nasution, HAM Dalam Islam, 13.
} 
Orang Islam diwajibkan memakai akal untuk memikirkan ayat-ayat Al- Qur'an supaya mengerti maksud dan tujuannya, lantaran ayat-ayat Al-Qur'an itu diturunkan untuk mereka yang mau berfikir, mau mengambil makna, mau mengetahui dan mau beristimbat. Dalam Al-Qur'an diterangkan: "Sesungguhnya Kami terangkan ayat-ayat ini sejelas-jelasnya bagi orang-orang yang mau mengerti" (Q.S.Al-An'am:98).

Islam amat mencela landasan orang-orang yang tak mempergunakan akalnya, orang-orang yang terikat fikirannya dengan kepercayaan dan paham-paham yang tak berdasar kepada landasan yang benar, yaitu mereka yang tak mau memeriksa apakah kepercayaan dan paham-paham yang disuruh orang terima atau dianut mereka itu benar, dan apakah berdasar kepada kebenaran atau tidak.

Kalau di Barat orang mengatakan bahwa Baco van Verulamlah yang mula-mula menggunakan "inductive methode" dalam berfikir, maka ketahuilah bahwa Muhammad s.a.w. sudah mengajarkan beberapa abad sebelum itu. Nabi Muhammad s.a.w. mengajarkan suatu cara berfikir yang sampai sekarang menjadi dasar bagi tiap-tiap penyelidikan yang dinamakan "wetenschap". Dalam Islam akal mendapat tempat yang mulia, dalam Islam akal tidak ditindas dan dipaksa, tapi dipergunakan dan diberi jalan, disalurkan untuk ketinggian dan keluhuran manusia. ${ }^{20}$

Berulangkali Allah berfirman: “Apakah kamu tidak berakal?'. Firman seperti itu berulang lebih dari sepuluh kali, seperti firmanNya mengakhiri kepada Rasul-Nya, Muhammad s.a.w., agar ia berhujjah kepada kaumnya bahwa Al-Qur'an itu semata-mata dari sisi Allah, bukan dari dirinya. Firmannya: “.... Sesungguhnya aku telah tinggal bersamamu beberapa lama sebelumnya. Maka apakah kamu tidak memikirkannya?" (Q.10:16).

Allah berfirman dalam surah Al-A'raf yang berbunyi: “ Dan sesungguhnya Kami jadikan untuk (isi) neraka jahanam 
kebanyakan dari jin dan manusia, mereka mempunyai hati (tetapi) tidak dipergunakannya untuk memahami (ayat-ayat Allah), dan mereka mempunyai mata (tetapi) tidak dipergunakannya untuk melihat (tanda-tanda kekuasaan Allah), dan mereka mempunyai telinga (tetapi) tidak dipergunakannya untuk mendengar (ayatayat Allah). Mereka itu sebagai binatang ternak, bahkan mereka lebih sesat lagi. Mereka itulah orang-orang yang lalai". (Q.7:179).

Demikian pula banyak sekali terdapat dalam Al-Qur'an ayatayat mengenai pertimbangan secara akal dan yang berhubungan dengan berfikir atau memikirkan. Barangsiapa yang memperhatikan dengan cermat ayat-ayat Al-Qur'an, pasti ia mengetahui bahwa pemeluk agama Islam adalah ahli menimbang, ahli berfikir, ahli menfungsikan akal dan ahli memahami serta menghayati. Orang-orang yang melalaikan, tidak mempergunakan akal sebagaimana mestinya hidupnya tak ubah seperti binatang ternak. Orang yang lalai itu sama sekali tidak memperoleh bagian keuntungan sedikit pun dari agama, lantaran mereka hanya mengambilnya yang lahiriyah saja secara buta semata, yang sudah barang tentu agama atau Al-Qur'an tidak bisa menyucikan jiwa dan tidak mampu mencerdaskan akal, dan dengan jiwa dan akal semacam itu mereka tidak akan bisa naik kepada tingkatantingkatan kesempurnaan, dengan ma'rifat dan mengenal Tuhan Yang Maha Agung dan Maha Indah.

Sebagian pujangga Barat mengemukakan sebuah pernyataan, yaitu: "Berfikir itu merupakan titik tolak kemajuan ummat manusia, dan tergantung kadar kualitas berfikirnyalah ukuran keunggulannya". Dengan datangnya agama Islam dengan Kitabnya ia melepaskan ikatan yang menjerat dan ia membebaskan mereka dari pada perbuadakan. Kemerdakaan berfikir yang dibawa Islam itu kemudian diketahui oleh bangsabangsa Barat. Sungguh para cendekiawan Barat telah mengakui kemajuan dan kepemimpinan ulama-ulama kita generasi 
terdahulu dalam hal kemerdekaan, dan mengakui buah kemerdekaan itu. ${ }^{21}$

\section{Penutup}

Kemerdekaan berfikir dan kebebasan menyampaikan pendapat adalah hak setiap warga negara untuk menyampaikan fikiran dengan lisan (pidato, dialog dan diskusi), tulisan (petisi, gambar, pamflet, poster, brosur, selebaran dan spanduk), secara bebas dan bertanggung jawab sesuai dengan ketentuan peraturan perundang-undangan yang berlaku. Kebebasan berfikir dan kebebasan berpendapat merupakan bagian dari kebebasan berekspresi (freedom of expression), yaitu kebebasan manusia untuk mengekspresikan diri dalam kehidupan masyarakat. Aspek lain yang terkait dalam lingkup kebebasan berekspresi adalah kebebasan berkesenian dalam segala bentuk dan manifestasinya. Oleh karena itu, kita harus menghargai pendapat orang lain dengan adanya kemerdekaan berfikir dan kebebasan menyampaikan pendapat tersebut.

\section{Daftar Pustaka}

Effendi, A Masyhur. HAM dalam Hukum Nasional dan Internasional. Jakarta: Ghalia Indonesia, 1994.

Idjehar, Muh. Budairi. Hak Asasi Manusia versus Kapitalisme. Yogyakarta: INSIST Press, 2003.

Muladi. Hak Asasi Manusia. Bandung: PT. Refika Aditama, 2005.

Nasution, Harun. Hak Asasi Manusia Dalam Islam. Jakarta: Pustaka Firdaus, 1995.

Natsir, M. Capita Selekta. Jakarta: Bulan Bintang, 1973.

Ridla, Muhammad Rasyid. Wahyu Ilahi Kepada Muhammad. Jakarta: PT. Dunia Pustaka Jaya, 1983.

21 Muhammad Rasyid Ridla, Wahyu llahi Kepada Muhammad, (Jakarta: PT. Dunia Pustaka Jaya, 1983), 405-408. 
Setiardja, A. Gunawan. Hak Asasi Manusia berdasarkan Ideologi Pancasila. Yogyakarta: Kanisius, 1993.

Suprapto. Cita Negara Pancasila, Demokrasi dan Hak Asasi Manusia. Jakarta: FH UI, Seminar Sehari, 26 Januari 1995.

Wahidin, Samsul. Hukum Pers. Yogyakarta: Pustaka Pelajar, 2006.

Wahidin, Samsul. Wacana Hukum Kritik dan Hak Untuk Berbeda Pendapat. Artikel pada Harian Surya, Surabaya,Senin 23 Maret 1998.

Wahyono, Padmo. Indonesia Berdasarkan Atas Hukum. Jakarta: Ghalia Indonesia, 1983.

http://rifalittleduck.wordpress.com/2013/01/06/hak-warga-negaradalam-kebebasan-berfikir-menyampaikan pendapat/ diakses 20 Mei 2013. 